\title{
HSPA1B wt Allele
}

National Cancer Institute

\section{Source}

National Cancer Institute. HSPA1B wt Allele. NCI Thesaurus. Code C104000.

Human HSPA1B wild-type allele is located in the vicinity of $6 \mathrm{p} 21.3$ and is approximately 3

$\mathrm{kb}$ in length. This allele, which encodes heat shock $70 \mathrm{kDa}$ protein $1 \mathrm{~A} / 1 \mathrm{~B}$, is involved in protein folding. 